\title{
Effect of Mulching on Cultivation, Weed Control and Moisture Conservation in Bitter Gourd (Momordica charantia L.)
}

\author{
Lovepreet Singh and Sukhwinder Singh Aulakh* \\ Department of Horticulture, School of Agriculture, Lovely Professional University, Phagwara \\ (Punjab), India 144401 \\ *Corresponding author
}

\section{A B S T R A C T}

Bitter gourd is an important commercial vegetable crop not only in India but also in whole of southeast Asia. Its fruits contain several active compounds and have many medicinal uses as evident from old texts as well as its popularity in modern medicine. Due to limited irrigation facilities and stress on natural resources, getting high yields with minimal input is vital for agriculture in the current scenario and judicious selection and use of mulching can play a big role in water conservation. In order to access the role of mulching on growth, yield and quality traits of bitter gourd, a field experiment was conducted at the Experimental Farm of School of Agriculture of Lovely Professional

\section{Keywords}

Vitamin C,

Moisture

conservation, Juice percentage, Weed control.

\section{Article Info}

Accepted:

24 June 2018

Available Online:

10 July 2018 University, Phagwara during the cropping season of March- July 2017. The experiment consisted of five treatments of different mulch materials (plastic, pebble, straw, FYM and control) applied to plots of bitter gourd variety Leena and treatments were assigned in a Randomized Complete Block Design with three replications. Data on plant growth, yield, earliness, weed growth, weed density and soil moisture conservation were recorded and analyzed with the SPSS package and charts and table were drawn in excel. Although,the effect of different mulch materials on various plant growth parameters of bitter gourd such as vine length $(\mathrm{m})$, numbers of branches per plant were nonsignificant; mulching was responsible for earlyflowering and results were significant. Flowering was early by one week when plastic mulch (34 days) was used and late by four days in FYM mulch (44 days) when compared to control (40 days). The higher yields as measured in terms of number of fruits per plant (25 fruits) and total fruit yield per plant $(1.86 \mathrm{~kg})$ were obtained when straw mulch was used followed by plastic and control. Mulching also affected the fruit size and the largest fruit $(14.47 \mathrm{~cm})$ was measured in plastic mulch and minimum smallest fruit sizes were recorded in straw $(13.60 \mathrm{~cm})$ and FYM mulch $(13.62 \mathrm{~cm})$. Two quality parameters viz., juice percentage and vitamin C were also observed and the highest juice percentage (24.86\%) was observed by use of FYM mulch material followed by use of pebble $(22.91 \%)$ and lowest juice percentage was observed with plastic mulch $(19.21 \%)$. In case of vitamin C, highest reading was recorded in pebble $(84.08 \mathrm{mg} / 100 \mathrm{gm})$ and least was recorded in FYM $(69.65 \mathrm{mg})$.Mulching in general was also very effective in controlling weeds and in conserving the soil moisture. Plastic mulch effectively controlled both the weed species (Nut grass and Crab grass) and also retained the highest soil moisture content (24\%).

\section{Introduction}

Bitter gourd (Momordica charantia L.) is one of the bitterest fruits that belongs to Cucurbitaceae family and its chromosome no. is $2 n=2 x=24$. The center of origin of bitter gourd is Indo-Burma and it is widely grown in
Southeast Asia, Africa, Philippines, Japan, China, Pakistan, the Caribbean, South America, Bangladesh, Shri Lanka, Nepal and India as a food and medicine. Moreover, in India it is widely spread in many states like Punjab, Haryana, Uttar Pradesh, Bihar, Gujarat, Maharashtra, Odisha, West Bengal, 
Tamil Nadu etc. (Gupta et al., 2011). Bitter gourd is an herbaceous vine that grows up to six meters in length. It bears simple, alternate leaves $5-13 \mathrm{~cm}$ across, with 4-6 deeply separated lobes and plant bears monoecious flowers (Gupta et al., 2011).Bitter Gourd has many essential antioxidants, vitamins, bioactive chemicals and minerals which are useful in treating a wide range of illnesses. It is useful against diabetes, controlling blood sugar level and offer many health benefits. Around 228 different medicinal compounds or molecules were isolated from the leaves, stem, callus tissue, endosperm of the plant. It is used as traditional medicine to cure asthma, cough, diabetes, fever, skin diseases, ulcers and wounds. Secondly, bitter gourd fruit is used as blood purifier and prevents liver damage (Panday et al., 2014).

Bitter Gourd is cultivated up to the altitude of $1500 \mathrm{~m}$ and it is an annual or perennial climber. It is cultivated during warm and rainy season i.e. during April-July and the duration of the crop is about three to four months. The optimum temperature required for plant growth is in the range of $24-27^{\circ} \mathrm{C}$ and optimum soil temperature for seed germination is $18^{0} \mathrm{C}$. The plant is adapted to rain fed conditions, but regular irrigation ensures high yield when there is no rainfall.Bitter gourd prefers a well-drained sandy loam soil, it should be rich in organic matter and the optimum $\mathrm{pH}$ of soil should be 6-6.7, but plants can tolerate up to $\mathrm{pH} 8.0$ alkaline soil. First harvesting of fruit is done 20-25days after fruit setting. Average fruit yield is 14t/ha (Ibarra et al., 2001), but can be increased by adopting various agronomic practices.

During 2016-2017 cropping season the total area under bitter gourd was 96,000 hectare producing total of 1085 tonnes of fruits. The average productivity was 11 tonnes per hectare in the both 2016-2017.In bitter gourd cultivation, mulching (German molsch meaning soft to decay) is very useful for controlling various types of weeds, conserving moisture and checking soil erosion. Mulching acts as protecting covering, and could be of organic (straw, FYM, rice hull, leave residue etc.) or inorganic material line plastic sheets of different colors and pebbles etc. Good mulch controls the variation in temperature and improves the physical, chemical and biological properties of soil. The organic mulches also add humus and nutrients. In general, it is found that in various vegetable crops, mulching boosts up yield by $20-60 \%$ over no mulch (Patil et al., 2013) as described in Table 1.

In the present study we evaluated the effect of different types of mulches on growth, yield and quality of bitter gourd. Additionally, effect of different mulches in weed control and on soil moisture conservation was also evaluated. Bitter gourd vines have a trailing growth habit. The vines can spread on ground or these can also be trained vertically on a suitable training framework. In either case weeds can pose major challenge in the initial growth period therefore the suppression/control of weeds is important. Later on, during advanced plant growth stage; the big leaves of the crop can smoother the weeds and therefore study of type and density of weeds is important in order to device suitable weed control methodology.

Another important benefit that can be associated with use of mulching is water conservation. It is well known that different types of mulching material are capable of conserving the soil moisture to a varying degree. Bitter gourd is a broad leaf crop but in the beginning the crop growth is slow and due wider planting distance most of the soil is exposed the environment factors leading to high rate of evaporation and moisture loss. A judicious selection and use of suitable mulch 
could prove beneficial in conserving the soil moisture.

\section{Materials and Methods}

The experiment was conducted at Main Experimental Farm of the Lovely Professional University Phagwara, Distt. Kapurthala, Punjab (India), during March - July cropping season of year 2017. The average minimum and maximum temperatures during March to July were $21^{\circ} \mathrm{C}$ to $31^{\circ} \mathrm{C}$ and the soil wc $\mathrm{x} 100$ loam. We evaluated a private sector $h$; bitter gourd (Leena F1 hybrid, Sakata Seed India (P) Ltd., Gurugram, Haryana) for its performance under five different types of mulches. The treatments were applied in Randomized Complete Block Design (RCBD) with three replications. Planting was done on raised beds $(2 \mathrm{~m} \times 2 \mathrm{~m} \times 15 \mathrm{~cm})$ and total of six plants were planted on a single bed in two rows with $100 \mathrm{~cm}$ row to row and $50 \mathrm{~cm}$ plant to plant spacing. A space of $50 \mathrm{~cm}$ was kept between the beds. Mulching treatments were applied 5 days after transplanting the crop to the main field.

Data were recorded on various plant growth parameters like vine length, number of branches to main vine, days to first flower; yield parameters viz., fruit length, number of fruits per plant, average weight of single fruit (g), average fruit yield/plant(kg); quality parameters viz.,juice percent and vitamin $\mathrm{C}$ content. Data were also recorded on weed density, growth rate and species richness. Finally, soil moisture percentage under different mulches was also determined.

The data for each treatment were reported after taking the average of 15 readings and statistical analysis were done on these averages. For estimation of Vitamin $\mathrm{C}$ content in bitter gourd fruits, Metaphosphoric acid 3\% solution was made by dissolving $30 \mathrm{gm}$ in one liter of distilled water. For titration 2-6- dichloroindophenol dye was made by first dissolving $42 \mathrm{mg}$ sodium bicarbonate in $120 \mathrm{ml}$ of distilled water and the procedure given in (Reference) was followed. Readings were recorded when constant dark pink color was stable. Calculations were done using this formula Ranganna (1979).

Ascorbic acid (mg/ 100gm) =

Titrate vol. $(\mathrm{ml}$ of dye used $) \times$ dye factor $\times$ vol. made up

$$
\begin{aligned}
& \text { Aliquot of sample taken for } \\
& \text { estimation } \times \text { vol. of sample }
\end{aligned}
$$

simuarıy, suice percentage was aetermined by dividing the weight of bitter gourd juice extracted with weight of bitter gourd fruit before extracting the juice and multiplying by 100 .

Observations on weed control were recorded at the time of first flowering. Number of weeds was counted in a predetermined fixed area of $0.25 \mathrm{~m}^{2}(50 \mathrm{~cm} \mathrm{X} 50 \mathrm{~cm}$ plot) as shown in Figure 1. For species richness we observed the total number of weed species in the above said plot and for determining the growth rate, plant height of weeds were measured at 2-day interval for a week.

To determine soil water conservation, random soil samples were taken from single plot of each replication and samples were combined and later a composite sample was drawn for analysis. From the composite sample, $100 \mathrm{~g}$ of soil were taken and dried in hot air oven for 24hours at $100^{\circ} \mathrm{C}$. Readings were recorded when constant weights of sample were reached.

Soil Moisture Percentage $=$

$$
\frac{\text { Fresh weight }- \text { Dry weight }}{\text { Dry weight }} \times 100
$$

Data were analyzed using Excel (2013) and 
SPSS version 17 (2016) package. Analysis of variance (ANOVA) tables were drawn with SPSS and graphical presentation (Charts, Histograms) was done with the help of Excel.

\section{Results and Discussion}

\section{Effect of mulch material on growth parameters}

Growth parameters like vine length, number of branches, days to flower etc. are vital in determining the crop stand, growth and ultimately good yield. For each parameter multiple data points were recorded (for details see material and method section). Here we are presenting some of the data as summarized in Table 2.

\section{Vine length}

Different types of mulching material used in this study do not have any significant effect on vine length of bitter gourd as shown in Table 2.

Vine length at 105 DAS was maximum straw mulch $(4.74 \mathrm{~m})$ followed by FYM $(4.70 \mathrm{~m})$ and least was observed in pebbles mulch $(4.62 \mathrm{~m})$. In a study on cucumber the authors recorded highest and significant vine length by using rice hull mulch (Ekwu et al., 2012). In the current study the highest vine length was also achieved in Straw material $(4.74 \mathrm{~m})$, although this is not significantly different from other mulching materials.

\section{Days to first flowering}

Significant differences were observed among different mulch treatments on number of days taken for first flowering. Plastic mulch had taken less number of days (34) followed by straw mulch (37), pebble (38) and control (40). Whereas, FYM (44) has taken more number of days for first flower.
First flowers could be attributed to the increased soil temperature of plastic mulch which was directly related to early initiation of flowers. Similar variations were also recorded by (Khan et al.2015) in sponge gourd and watermelon (Parmar 2011 and Parmar et al.2013). Days to flowering is considered a very important trait in vegetable since precocious yield are capable of fetching premium price in the market. Based on our data plastic mulching can advance the crop by about one week.

\section{Effect of mulch material on yield parameters}

Yield parameters like fruit length $(\mathrm{cm})$, number of fruits per plant, average weight of single fruit $(\mathrm{gm})$, average fruit yield $(\mathrm{kg})$ etc. are vital in for determining the good yield. The effects of mulching treatments on fruit length of bitter gourd (average of various data points) were found to be significant. Data have been presented in Table 2 and Figures 2 and $3 \mathrm{~A}$. Among all these mulching material the maximum fruit length were observed in plastic mulch $(14.47 \mathrm{~cm})$ followed by pebble and control $(14.37 \mathrm{~cm})$ and least was observed in straw mulch $(13.60 \mathrm{~cm})$. Similar variation was also recorded by (Khan et al., 2015) sponge gourd and (Sylvestre et al., 2014) water melon.

The effect of mulching treatments on maximum number of fruit from plot was mainly due to increasing number of primary and secondary branches per plant, and number of fruits per plant. Significant differences were observed among different mulch applications. Straw mulch produced maximum fruits (25.17) followed by plastic and FYM mulch (23.28) and control mulch (23) while, minimum number of fruits were observed in pebble mulch (22.61) which were on par with each other. Similar variations were also recorded by (Birbal et al., 2014) squash melon. 
Table.1 Yield comparison in vegetable crops with and without use of plastic mulching

\begin{tabular}{|c|c|c|c|}
\hline \multirow{2}{*}{ Crop } & \multicolumn{2}{|c|}{ Yield (t/ha) } & Increase in \\
\cline { 2 - 3 } & No mulch & With mulch & yield (\%) \\
\hline Bitter Gourd & 20.12 & 25.63 & 27.39 \\
\hline Broccoli & 14.20 & 26.25 & 61.85 \\
\hline Cauliflower & 18.85 & 26.24 & 60.78 \\
\hline Brinjal & 37.63 & 44.61 & 27.34 \\
\hline Tomato & 68.25 & 87.84 & 34.57 \\
\hline Okra & 6.14 & 9.38 & 25.44 \\
\hline
\end{tabular}

Table.2 Mean values of observed plant parameters of bitter gourd under different mulching materials

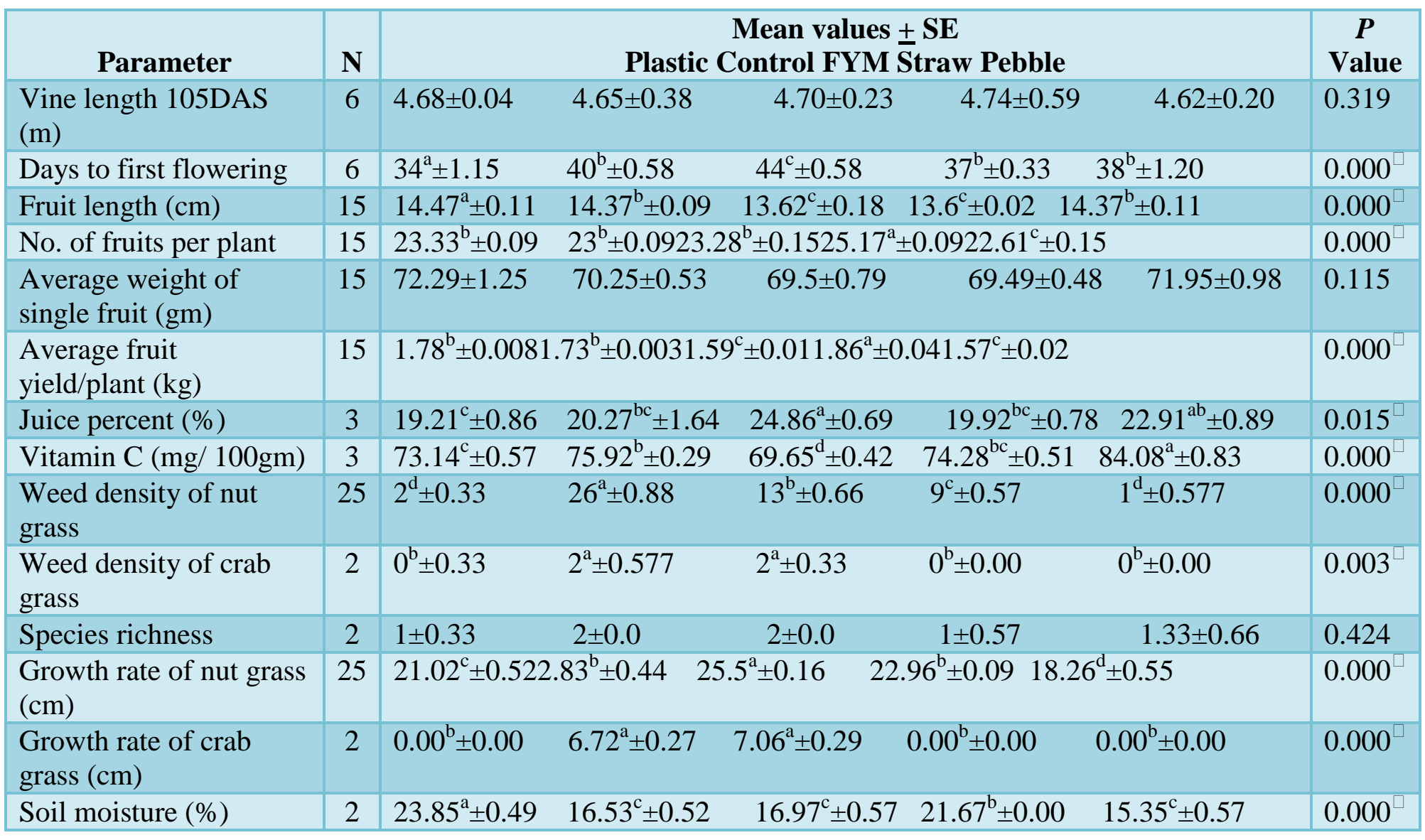


Figure.1 Measurement of weed density and species richness in bitter gourd crop grown by using different mulches

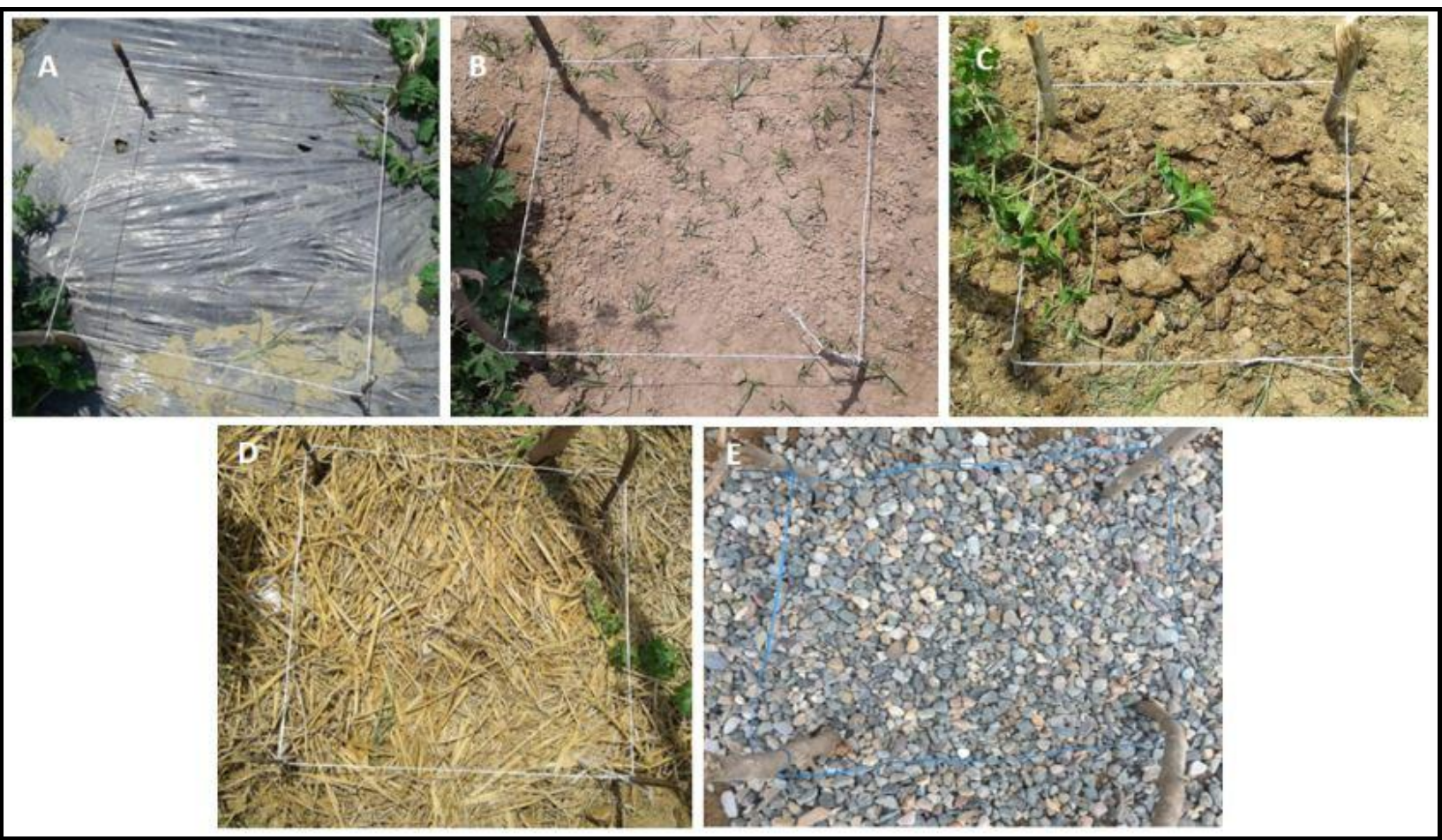

Figure.2 Effect of mulch material on fruit length (A) and average fruit yield (B)of bitter gourd. Significant effects were observed in case of plastic and straw mulch from all other treatments, non-significant result were observed in average fruit weight. Significant cut off was based on $p$ $<0.05$ value

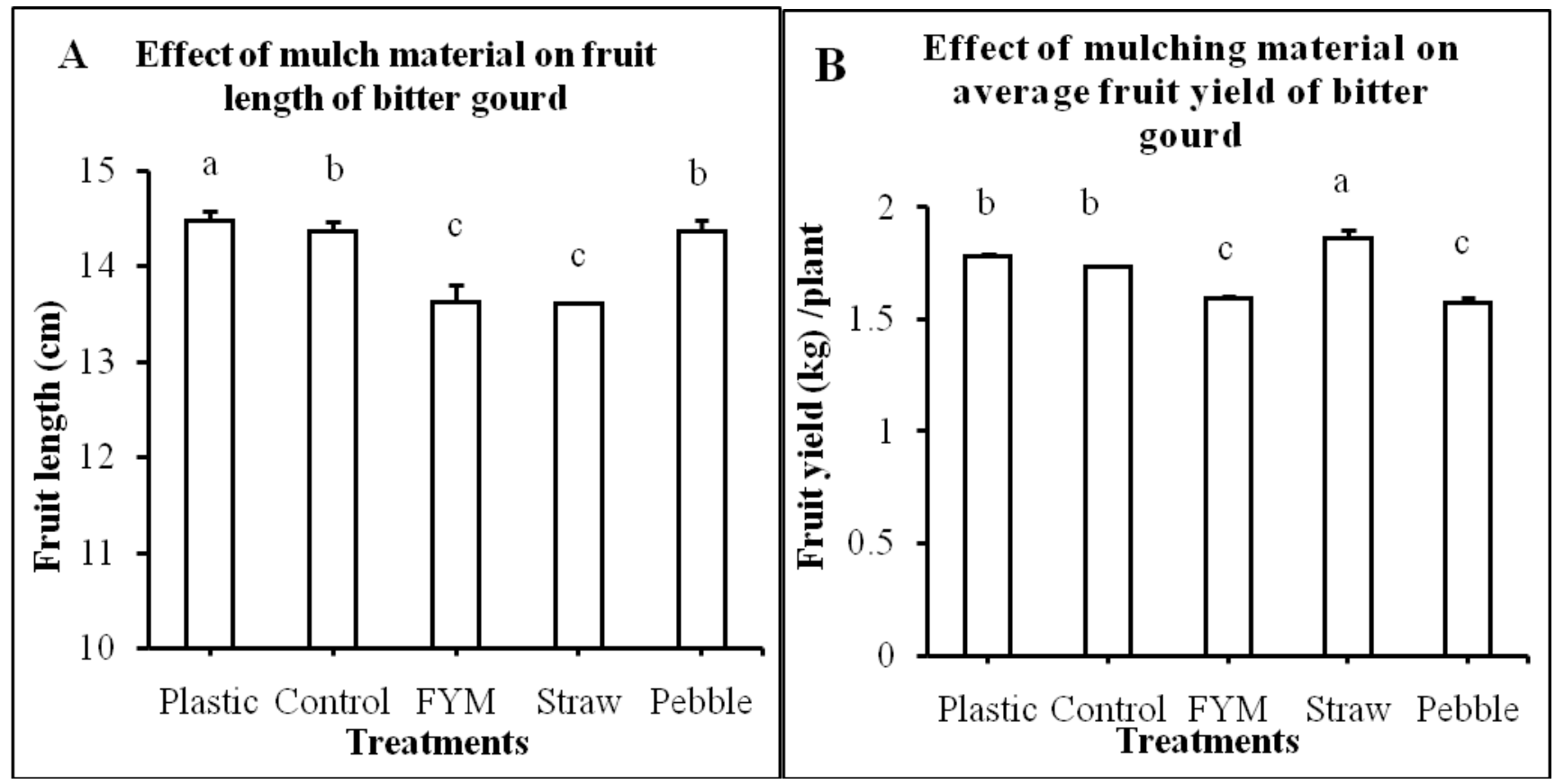


Figure.3 Different fruit quality parameter like shape and size (A) and juice content (B) of bitter gourd



Figure.4 Quality parameters like juice percentage (A) and vitamin C (B) of bitter gourd by using various types of mulches

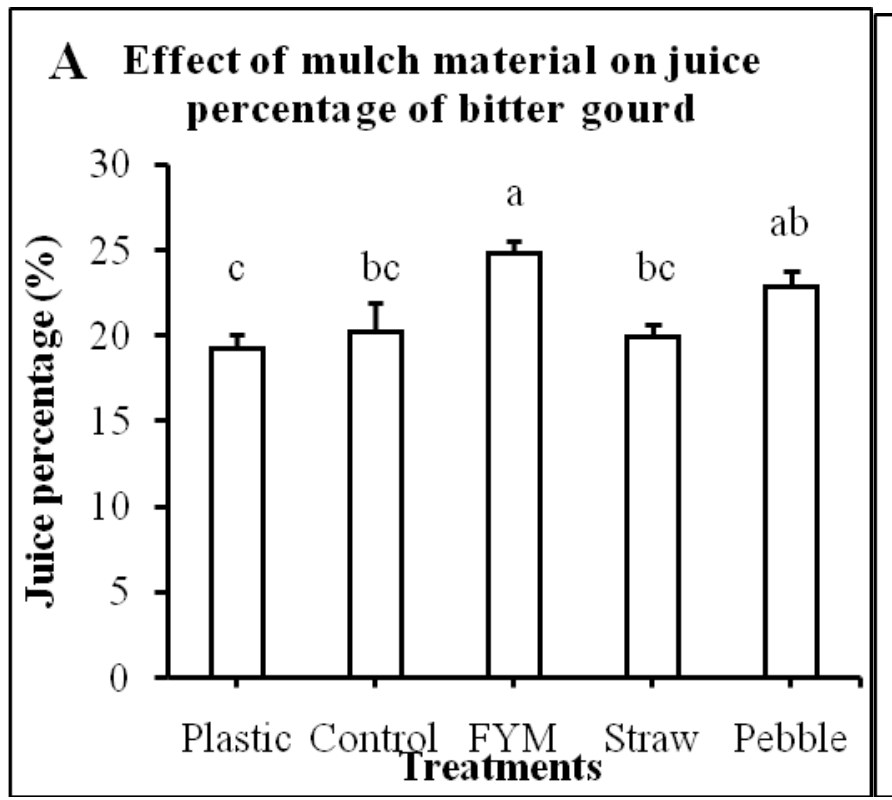

Significant differences were observed among different mulch applications with respect to average fruit yield. Straw mulch $(1.86 \mathrm{~kg})$ produced the highest yield followed by plastic mulch $(1.78 \mathrm{~kg})$, control $(1.73 \mathrm{~kg})$, FYM $(1.59 \mathrm{~kg})$, and lowest yield was produced by using pebble $(1.57 \mathrm{~kg})$. Similar variations were also recorded by (Birbal et al., 2014) in squash melon.

\section{B Effect of mulch material on vitamin $\mathrm{C}$ of bitter gourd}

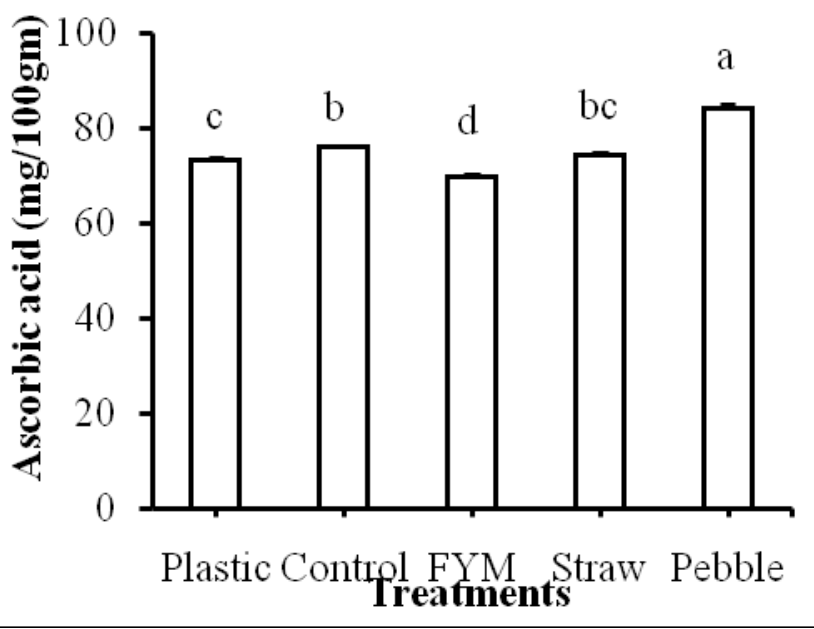

Effect of mulch material on quality parameters

In this study two main quality parameters of bitter gourd fruits viz., juice percentage and vitamin $\mathrm{C}$ content were studied (Figure 3B). Juice percentage determines the palatability quality of the fruits and also influence the vitamin $\mathrm{C}$ content. 
Bitter gourd juice has many compounds that have medicinal values and therefore determining the juice percentage is important. Significant differences were observed among different mulching treatments, FYM resulted in maximum juice recovery percentage (24.86\%) followed by pebble mulch (22.91\%) and least juice percentage $(19.21 \%)$ were recorded in plastic mulch. The data (Figure 4) revealed that there were significant differences in ascorbic acid (mg/100gm) content of bitter gourd fruit when grown under different types of mulching material. Pebble mulch $(84.08 \mathrm{mg} / 100 \mathrm{gm}$ fruit weight) produced highest amount of ascorbic acid followed by control mulch $(75.92 \mathrm{mg})$, straw $(74.28 \mathrm{mg})$ and least were observed in FYM (69.65mg).

\section{Effect of mulch material on weed growth and density}

We have studied two important weeds of bitter gourd viz., nut grass and crab grass and the results are summarized in Table 2. The data revealed that there were significant differences in weed density of nut grass and crab grass, under observed area of $0.25 \mathrm{~m}^{2}$ $(50 \mathrm{~cm} \times 50 \mathrm{~cm}$ plot). For instance, the highest number of nut grass plants were recorded in control plot (26) followed by FYM (13), Straw (9) and very few nut grass plants were recorded in plastic (2) and pebble (1). In case of crab grass, there were only sporadic weed population with only two plants were observed in control plot and there was no appearance of this plant in any of the treatments used in this study. Similar variations were also observed in summer squash (Coolong, 2010), tomato (Rajablariani et al., 2012), chilli (Ashrafuzzaman et al., 2011). In another study by Schonbeck (1999), similar results were recorded in major vegetable crops like capsicum, tomato, cabbage etc. As already mentioned we studied two weed species in the present study and have not observed any other weed species.
Both the weeds were present in control plot and plot in which FYM were used as mulching material. In other treatments (plastic, straw and pebble) only nut grass weeds were observed. Based on our analysis, the results of species richness are nonsignificant. Most of the mulch materials were able to decrease the weed density to a significant lower level. Some weeds that we observed in FYM could be present the FYM material used.

Plant height of weeds were determined and presented in Table 2 as an indicator of growth rate. The information revealed that there were significant differences in the growth rate of both the weeds when different mulching material was used. In case of nut grass, highest plant height was recorded with FYM mulch $(25.50 \mathrm{~cm})$ followed by Straw $(25.97 \mathrm{~cm})$ and lowest height of weed were observed in plastic $(21.02 \mathrm{~cm})$ and pebble $(18.26 \mathrm{~cm})$. However in crab grass, which was reported only in control plot and FYM mulch, there were no significant differences in the growth rate. Similar variations were also observed (Coolong, 2010) in summer squash, chilli (Ashrafuzzaman et al., 2011).

\section{Effect of mulch material on water conservation}

The data represent in Table 2 exhibited that effect of mulching treatments on soil moisture of bitter gourd show significant differences among different mulch applications. Water conservation was measured in terms of percentage of soil moisture content present in the soil at a given time. Highest soil moisture percentage were observed in plastic mulch $(23.85 \%)$ followed by straw $(21.67 \%)$ and lowest were recorded in pebble mulch (15.35\%). Similar variation was also observed by Rao et al., (2017) and Parmar (2011) in watermelon, and by (Schonbeck 1999) and (Awasthi et al., 2006) in brinjal. 
From the results of present study, following broad conclusions can be drawn which may prove beneficial in commercial cultivation of bitter gourd.

1. Mulching is useful for getting early marketable yields: Use of plastic mulch have advanced the bitter gourd crop by one week compared to control.

2. Mulching increases the total yield of bitter gourd: Although all type of mulches were useful in one way or another the highest total yield and large fruits were obtained with plastic mulching.

3. Mulching leads to better quality of produce: Juice percent was highest when pebble were used as mulch and FYM mulch lead to highest vitamin $\mathrm{C}$ content.

4. Weed control and moisture conservation: Both plastic and pebble mulching effectively controlled the weeds, however the highestmoisture conservation was achieved inplastic mulch followed by straw mulching.

\section{References}

Ashrafuzzaman, M., Halim, M.A., Ismail, M.R., Shahidullah, S.M., and Hossain, M.A. (2011). Effect of plastic mulch on growth and yield of chilli (Capsicum annuum L.) Brazilian Archives of Biology and Technology, 24 (2): 15168913.

Awasthi, O. P., Singh, I. S., and Sharma, B. D. (2006). Effect of mulch on soilhydrothermal regimes, growth and fruit yield of brinjal under arid conditions. Indian journal of Horticulture, 63(2): 192-194.

Birbal, Rathore, V.S., Nathawat, N.S., Soni M.L., and Yadava, N.D. (2014). Response of squash melon (citrullus vulgaris var. Fistulosus) to FYM and mulching under rainfed condition of hot arid region of Rajasthan. Indian Journal of Agricultural Research, 48 (2): 149-
153.

Coolong, T. (2010). Performance of paper mulches using a mechanical plastic layer and water wheel transplanter for the production of summer squash. Department of Horticulture Science, 20 (2): 319-324.

Ekwu, L.G., Nwokwu, G. N., and Utobo, E.B. (2012). Effect of mulching materials and pruning on growth and yield of cucumber (Cucumis sativus L.). International Journal of Agriculture and Rural Development, 15(2): 10141021.

Gupta, M., Sharma, S., Gautam., A.K., and Bhadauria, R. (2011). Momordica charantia linn. (karela): nature's silent healer. International Journal of Pharmaceutical Sciences Review and Research, 11(1): 32-37.

Ibarra, L., Flores, J., and Díaz-Pérez, J. C. (2001). Growth and yield of muskmelon in response to plastic mulch and row covers. Scientia Horticulturae, 87(1-2): 139-145.

Khan, M., Abid, S., Hussain, Z., and Mateen, K. (2012). Effect of different weed control method on weeds and yield of chillies (Capsicum annuum L.). Pakistan Journal of Weed Science Research, 18 (1): 71-78.

Khan, S., Pal, M., and Kumar, V. (2015). Influence of different mulches on growth and yield of sponge gourd (Luffa Clyndrica L.). Plant Archives, 15(1): 393-395.

Panday, D. R., Rauniar, G. P., and Rajbhandari, M. D. K. (2014). Momordica charantia (karela); an antidiabetic.World journal of pharmacy and pharmaceutical sciences, 4(1): 8499.

Parmar, M. P. (2011). "Effect of mulching material on growth, yield and quality of watermelon (Citrullus lanatus Thunb)" $c v ., K_{R} A N^{\prime \prime}$ (Doctoral dissertation, jau, 
junagadh).

Parmar, H. N., Polara, N. D., and Viradiya, R. R. (2013). Effect of mulching material on growth, yield and quality of watermelon (Citrullus lanatus Thunb) Cv. Kiran. Universal Journal of Agricultural Research, 1(2): 30-37.

Patil Shirish, S., Kelkar Tushar, S., and Bhalerao Satish, A. (2013). Mulching: A soil and water conservation practice. Research Journal of Agriculture and Forestry Sciences. 1(3): 26-29.

Rajablariani, H. R., Hassankhan, F., and Rafezi, R. (2012). Effect of colored plastic mulches on yield of tomato and weed biomass. International Journal of Environmental Science and Development, 3(6): 590-593.

Ranganna S. (1979). Manual of analysis of fruits and vegetable products. Tata
McGraw Hill Book Company, New Delhi. p 634.

Rao, K. V. R., Bajpai, A., Gangwar, S., Chourasia, L., and Soni, K. (2017). Effect of Mulching on Growth, Yield and Economics of Watermelon (Citrullus lanatus Thunb). Environment and Ecology, 35(3): 2437-2441.

Schonbeck, M. W. (1999). Weed suppression and labor costs associated with organic, plastic, and paper mulches in smallscale vegetable production. Journal of Sustainable Agriculture, 13(2), 13-33.

Sylvestre, H., Bosco, N. J., Emmanuel, N., and Christine, U. (2014). Growth and yield of watermelon as affected by different spacing and mulching types under Rubona conditions in Rwanda. Scholarly Journal of Agricultural Science, 4(10): 517-520.

\section{How to cite this article:}

Lovepreet Singh and Sukhwinder Singh Aulakh. 2018. Effect of Mulching on Cultivation, Weed Control and Moisture Conservation in Bitter Gourd (Momordica charantia L.). Int.J.Curr.Microbiol.App.Sci. 7(07): 3341-3350. doi: https://doi.org/10.20546/ijcmas.2018.707.389 